\title{
Tipikal Kendala Guru PAUD dalam Mengajar pada Masa Pandemi Covid 19 dan Implikasinya
}

\author{
Mubiar Agustin ${ }^{\otimes}{ }^{凶}$, Ryan Dwi Puspita ${ }^{2}$,Dinar Nurinten ${ }^{3}$, Heni Nafiqoh ${ }^{4}$ \\ Pendidikan Guru Pendidikan Anak Usia Dini, Universitas Pendidikan Indonesia ${ }^{1}$ \\ Pendidikan Guru Sekolah Dasar, Institut Keguruan dan Ilmu Pendidikan Siliwangi ${ }^{2,4}$ \\ Pendidikan Guru Pendidikan Anak Usia Dini, Universitas Islam Bandung 3 \\ DOI: $\underline{10.31004 / o b s e s i . v 5 i 1.598}$
}

\begin{abstract}
Abstrak
Pandemi covid 19 menjadikan semua jenjang pendidikan termasuk PAUD menghentikan kegiatan pembelajaran secara tatap muka dan berganti dengan sistem daring. Hal ini menimbulkan kekagetan budaya dan kendala dalam proses pembelajaran. Tujuan penelitian ini adalah untuk mengungkap tipikal kendala mengajar guru PAUD saat pandemi covid 19 dan implikasinya pada kegiatan pembelajaran berbasis konsep normal baru. Metode yang digunakan dalam penelitian ini adalah metode survey. Data penelitian diperoleh secara online menggunakan media google form. Sampel dalam penelitian ini adalah 645 guru yang berada di wilayah Jawa Barat. Hasil penelitian menunjukkan bahwa kendala mengajar yang dialami guru PAUD pada masa pandemi covid 19 berada pada empat indikator yaitu kendala komunikasi, metode pembelajaran,materi dan biaya serta penggunaan teknologi dengan kecenderungan prosentase yang tinggi berada pada kategori sering dan kadangkadang. Tentunya perlu solusi untuk mengatasi masalah ini supaya tidak berdampak secara sistemik serta supaya guru PAUD lebih siap menerapkan kegiatan pembelajaran berbasis konsep normal baru.
\end{abstract}

Kata Kunci: guru paud; covid 19; new normal.

\begin{abstract}
Pandemi covid 19 made all levels of education including Paud stopping learning activities face-to-face and changing with online systems. This raises the shock of culture and obstacles in the learning process. The aim of this research is to uncover the typical constraints of teaching PAUD's as a covid 19 pandemic and its implications on learning activities based on new normal concepts. The method used in this research is the survey method. Research data is obtained online using google form media. The samples in this study were 645 teachers in the West Java region. The results showed that teaching constraints experienced by Paud teachers at the time of covid 19 pandemic were on four indicators i.e. communication constraints, learning methods, materials and costs as well as the use of technology with high tendency of percentage are in frequent and sometimes categories. It certainly needs a solution to solve this problem so as not to have systemic impact and so PAUD teachers better ready to implement a new normal concept-based learning activities.
\end{abstract}

Keywords: paud teachers; covid 19; new normal.

Copyright (c) 2020 Mubiar Agustin, Ryan Dwi Puspita ,Dinar Nurinten, Heni Nafiqoh

$\triangle$ Corresponding author :

Email Address : mubiar@upi.edu (Jalan Setia Budi No 229, Bandung, Jawa Barat)

Received 9 June 2020, Accepted 17 June2020, Published 20 June 2020 


\section{PENDAHULUAN}

Pandemi covid 19 yang terjadi di hampir seluruh belahan dunia membawa dampak yang cukup serius. Bukan hanya ekonomi, kesehatan dan juga keamanan yang terkena langsung dampaknya, kegiatan pendidikan juga terkena dampaknya langsung. Di seluruh negara terdampak covid 19 tidak terkecuali di Indonesia, semua jenjang pendidikan menghentikan kegiatan pembelajaran secara tatap muka dan berganti dengan sistem daring atau belajar jarak jauh (Kementerian Pendidikan dan Kebudayaan Republik Indonesia, 2020). Akibatnya terjadi perubahan yang sangat tiba-tiba dan tidak sedikit menimbulkan kekagetan budaya, baik pada guru juga pada anak didik.

Kekagetan budaya ini salah satunya berdampak kepada terganggunya sistem penyesuaian sosial dalam pembelajaran, terganggunya motivasi berprestasi, dan interaksi pembelajaran menjadi tidak optimal (Agustin, 2011), (Ernofalina, 2017), (Pramudiana \& Setyorini, 2019). Padahal kegiatan pembelajaran yang kondusif adalah kegiatan yang membentuk suasana interaksi yang menyenangkan, mendorong anak untuk mencoba, terjadi dialog tanpa batas, dan anak didik mendapatkan kesempatan yang luas untuk mengekspresikan diri dalam melejitkan potensi diri yang mereka miliki (Agustin, Setiyadi, \& Puspita, 2020).

Lebih jauh pembelajaran yang efektif akan membekali anak dengan pengalamanpengalaman menyenangkan dan bermakna yang akan mengendap dalam pikiran anak sepanjang masa sebab belajar yang baik pada dasarnya adalah pembelajaran yang memebrikan anak pengalaman yang menantang, kreatif dan konstruktif yang tujuan akhirnya adalah membantu anak untuk dapat memecahkan masalah dimasa yang akan datang (Daulae, 2014). Pembelajaran yang kondusif tersebut menjadi sulit tercapai pada masa pandemi covid 19 ini sebab guru sebagai aktor utama dalam pembelajaran kesulitan dan mengalami banyak kendala untuk menciptakan situasi pembelajaran yang positif. Proses belajar mengajar tidak terlepas dari strategi, metode dan media yang digunakan guru (Panjaitan, Yetti, \& Nurani, 2020). Pembelajaran positif merupakan realisasi dari aksi guru untuk unjuk profesionalisme dengan berbasis kepada pengalaman dan praktek yang mereka lakukan dan miliki, jika ini terkendala maka akan sulit diperoleh peningkatan mutu pembelajaran apalagi jika unsur-unsur interaksi pedagogik dalam pembelajaran ikut memudar (Gore et al., 2017), (Ronkainen, Kuusisto, \& Tirri, 2019). Apalagi pada kegiatan pembelajaran anak usia dini di PAUD pembelajaran yang berkualitas akan sulit tercapai sebab pembelajaran di PAUD menuntut guru untuk lebih dekat baik secara psikologis juga secara fisik sebab adegan pembelajaran untuk anak usia dini lebih bersifat non formal, dilakukan melalui kegiatan dengan banyak aktivitas bermain dan tidak memiliki target capaian prestasi yang bersifat akademik akan tetapi optimalisasi perkembangansehingga guru dapat menciptakan suasana pembelajaran yang nyaman dan aman bagi anak (Maiza \& Nurhafizah, 2019). Tidak dapat terbantahkan bahwa peran guru dalam pembelajaran memegang posisi yang sangat penting, strategis dan bahkan menjadi kunci untuk mencapai pembelajaran yang bermutu dan efektif.

Terkait dengan perilaku mengajar yang efektif ini adalah menyampaikan pembelajaran dengan terpusat pada anak, terjadi interaksi yang mendidik antara guru dengan anak didik, tercipta suasana yang demokratis, terdapat variasi metode mengajar, gurunya profesional, ada bahan ajar yang berguna dan sesuai dengan perkembangan anak, lingkungan yang aman dan nyaman serta ditunjang oleh sarana karena sifat dari pembelajaran efektif adalah yang menekan peserta didik secara aktif (Yusuf, 2017).

Untuk mewujudkan pembelajaran yang efektif maka guru sebagai tokoh utama dalam pembelajaran diwajibkan menjadi guru yang efektif pula, yaitu guru yang menggunakan waktu mengajar secara maksimal, menyampakan materi dengan metode yang bervariasi, memantau proram dan kemajuan melalui penilaian peserta didik, merancang kesemparan belajar bagi peserta didik untuk menerapkan pengalaman belajar,bersedia 
mengulang materi ketika anak belum memahaminya, menetapkan target belajar untuk setiap anak (Setyosari, 2017).

Selain kesulitan untuk menciptakan situasi pembelajaran yang efektif, dampak covid 19 juga menciptakan komunikasi dalam kegiatan pembelajaran anak tidak terjadi secara utuh sebab antara guru dengan anak terjadi jarak, jika ada interaksi secara online juga guru dan anak tidak bisa menjalin komunikasi pembelajaran secara optimal, padahal tatap muka dalam kegiatan pembelajaran apalagi pada kegiatan pembelajaran di PAUD memiliki nilai peran yang sangat subtantif dalam membantu anak didik mencapai kesuksesan dalam belajar (Duta, Panisoara, \& Panisoara, 2015), (Khan, Khan, Zia-Ul-Islam, \& Khan, 2017). Dengan kegiatan bertatap muka akan membuka jendela pikiran yang lebih jernih, kendali diri yang lebih terarah, dan kondisi emosi yang lebih stabil sehingga anak akan menjadi pribadi yang sehat baik secara fisik, psikologis bahkan secara spiritual. Namun dalam hal ini juga guru harus mengenal, memahami dan mampu menggunakan teknologi (Rohita, 2020) terutama aplikasi dalam pembelajaran online untuk menyesuaikan dengan kebutuhan masa covid 19.

Kegiatan pembelajaran yang menyajikan tatap muka antara guru-anak didik juga turut membangkitkan motivasi belajar pada anak yang lebih tinggi, mereduksi kecemasan dan stres serta dapat menimbulkan rasa percaya diri oleh karena itu berdasarkan hasil penelitian (Purwanto et al., 2020) dengan adanya pembelajaran online anak-anak jadi tidak bisa menyerap dengan baik materi yang disampaikan oleh guru, anak-anak tidak dapat beerinteraksi dan bermain bersama teman-temannya sehingga mereka mudah setress. Kendala-kendala yang dihadapi guru PAUD dalam mengajar selama masa covid 19 perlu mendapatkan tanggapan yang serius dan ditindak lanjut dalam bentuk kajian ilmiah supaya diperoleh data yang valid, realiabel dan dapat dipertanggungjawabkan. Apalagi dalam jangka waktu dekat akan diterapkan era normal baru dalam pembelajaran yang menuntut kecermatan, penerapan prosedur ketat dan juga kehati-hatian dalam penerapannya sebab akan digelar kegiatan pembelajaran ditengah-tengah pandemi yang masih mewabah. Berdasarkan beberapa argumen yang diapaparkan di atas maka penelitian ini memfokuskan kajian tentang tipikal kendala guru PAUD dalam mengajar masa pendemi covid 19 dan implikasinya pada kesiapan pembelajaran era normal baru. Tujuan penelitian ini adalah untuk mengungkap tipikal kendala mengajar guru PAUD saat pandemi covid 19 dan implikasinya pada kegiatan pembelajaran berbasis konsep normal baru.

\section{METODOLOGI}

Pendekatan yang digunakan dalam penelitian adalah kuantiaitif dengan metode yang digunakan adalah survey dengan mendeskripsikan secara kuantitatif kecenderungankecenderungan perilaku dari suatu populasi dengan meneliti sampel populasi tersebut (Creswell, 2017). Dalam penelitian ini perilaku-perilaku yang dimaksud adalah terkait dengan tipikal kendala mengajar yang dialami guru PAUD saat masa pandemi covid 19.

Data penelitian diperoleh secara online menggunakan media google form. Dalam penelitian ini jumlah responden yang menjadi sampel dalam penelitian ini adalah 645 guru yang terdiri dari 620 orang guru dengan jenis kelamin perempuan dan 25 orang berjenis kelamin laki-laki yang berada di wilayah Jawa Barat. Adapun sebarannya adalah 66,7 \% guru mengajar pada Pendidikan Anak Usia Dini (PAUD), 22,5 \% mengajar di Taman Kanakkanak (TK) dan 11,8 \% mengajar di Raudhatul Athfal (RA).

Instrumen yang digunakan dalam penelitian ini adalah angket tentang kendala mengajar guru PAUD yang dibagi menjadi 4 indikator yaitu dengan (1) indikator Kendala Komunikasi (dengan pernyataan nomer 1 sd 9), (2) indikator Kendala Metode Pembelajaran (dengan pernyataan nomer 10-12), (3) indikator Kendala Materi (dengan pernyataan nomer 13-16), dan (4) indikator Kendala Biaya \& Penggunaan Teknologi (dengan pernyataan nomer 17-20). Jumlah pernyataan yang diajukan dalam angket ini 20 pernyataan dengan alternatif jawaban menggunakan skala likert (Sangat Sering, Sering, Kadang-kadang, Pernah, Tidak 
DOI: 10.31004/obsesi.v5i1.598

pernah). Pengolahan data menggunakan sistem docs.google.com.documen yang secara langsung menghasilkan deskripsi data berdasarkan pernyataan-pernyataan yang dijawab oleh responden.

Adapun tahapan-tahapan penelitiannya dijelaskan pada gambar 1 di bawah ini.

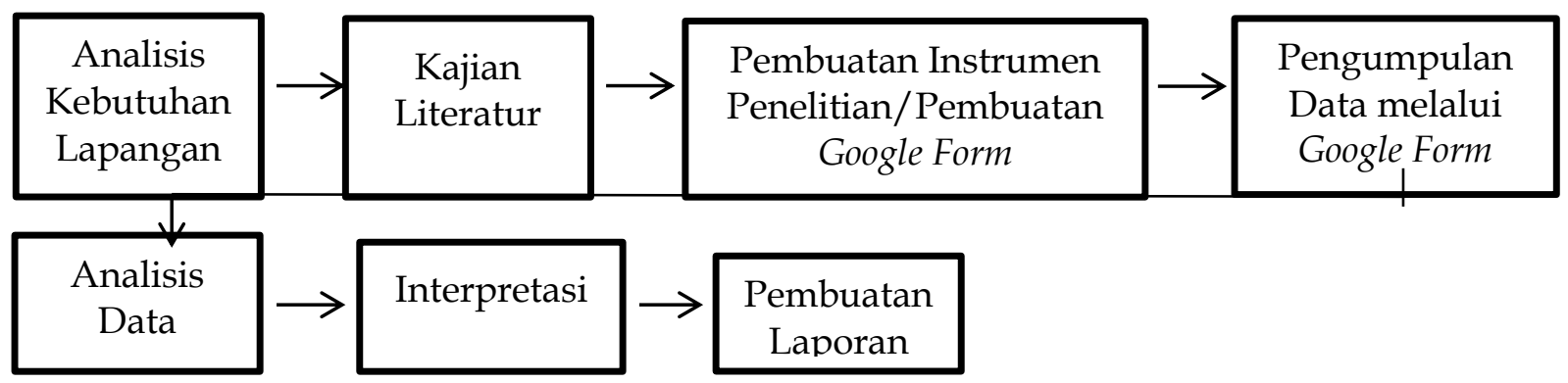

Gambar 1 Tahapan Penelitian

\section{HASIL DAN PEMBAHASAN}

Hasil penelitian yang akan diuraikan mencakup 4 indikator yaitu (1) indikator Kendala Komunikasi (dengan pernyataan nomer 1 sd 9), (2) indikator Kendala Metode Pembelajaran (dengan pernyataan nomer 10-12), (3) indikator Kendala Materi (dengan pernyataan nomer 13-16), dan (4) indikator Kendala Biaya \& Penggunaan Teknologi (dengan pernyataan nomer 17-20). Hasil penelitian pada indikator Kendala Komunikasi menunjukkan hasil sebagaimana tertuang pada tabel 1 berikut ini .

Tabel 1 Kendala Komunikasi

\begin{tabular}{|c|c|c|c|c|c|c|}
\hline No & $\begin{array}{l}\text { Pernyataan } \\
\text { Kendala Komunikasi } \\
\end{array}$ & $\begin{array}{l}\text { Sangat } \\
\text { Sering }\end{array}$ & Sering & $\begin{array}{l}\text { Kadang- } \\
\text { Kadang }\end{array}$ & Pernah & $\begin{array}{l}\text { Tidak } \\
\text { Pernah }\end{array}$ \\
\hline 1 & $\begin{array}{l}\text { Sulit untuk menemukan kesamaan pemikiran } \\
\text { dengan orang tua tentang tujuan belajar anak } \\
\text { (terkait target yang harus dicapai) }\end{array}$ & $7,3 \%$ & $34,5 \%$ & $35,5 \%$ & $18,2 \%$ & $6,2 \%$ \\
\hline 2 & $\begin{array}{l}\text { Banyak tuntutan dari orang tua yang } \\
\text { sebenarnya tidak menjadi kebutuhan anak }\end{array}$ & $9,4 \%$ & $32,6 \%$ & $27,9 \%$ & $18,4 \%$ & $11,7 \%$ \\
\hline 3 & $\begin{array}{l}\text { Orang tua tidak memberikan informasi yang } \\
\text { sebenarnya terjadi tentang kegiatan anak di } \\
\text { rumah }\end{array}$ & $15,3 \%$ & $19,8 \%$ & $42,2 \%$ & $19,5 \%$ & $3,2 \%$ \\
\hline 4 & $\begin{array}{l}\text { Terjadi kesulitan berkoordinasi dengan teman } \\
\text { sejawat dalam membuat keputusan (salah } \\
\text { satunya karena kendala keterbatasan akses } \\
\text { internet) }\end{array}$ & $8,5 \%$ & $22,8 \%$ & $28,7 \%$ & $22,1 \%$ & $17,9 \%$ \\
\hline 5 & $\begin{array}{l}\text { Tidak menemukan kesepakatan waktu } \\
\text { dengan orang tua untuk mendiskusikan } \\
\text { tentang belajar anak di rumah }\end{array}$ & $4,2 \%$ & $17,8 \%$ & $33,5 \%$ & $22,5 \%$ & $22,8 \%$ \\
\hline 6 & $\begin{array}{l}\text { Orang tua sulit dihubungi (misalnya via } \\
\text { telepon atau WA) }\end{array}$ & $9 \%$ & $24,8 \%$ & $32,9 \%$ & $21,8 \%$ & $11,6 \%$ \\
\hline 7 & $\begin{array}{l}\text { Kesulitan berinteraksi secara langsung } \\
\text { dengan anak melalui media online }\end{array}$ & $14,8 \%$ & $35 \%$ & $25,9 \%$ & $16,4 \%$ & $7,9 \%$ \\
\hline 8 & $\begin{array}{l}\text { Kesulitan berkomunikasi dengan orang tua } \\
\text { dan anak karena tidak memiliki alat } \\
\text { komunikasi (HP/Laptop) }\end{array}$ & $13,4 \%$ & $28,4 \%$ & $18,8 \%$ & $23 \%$ & $16,4 \%$ \\
\hline 9 & $\begin{array}{l}\text { Kesulitan membangkitkan semangat belajar } \\
\text { anak }\end{array}$ & $6 \%$ & $24,1 \%$ & $39 \%$ & $22,5 \%$ & $8,8 \%$ \\
\hline
\end{tabular}

Hasil penelitian terkait indikator Kendala Metode Pembelajaran menunjukkan hasil sebagaimana tertuang pada tabel 2 berikut ini. 
Tabel 2 Kendala Metode Pembelajaran

\begin{tabular}{llccccc}
\hline No & Kendala Metode Pembelajaran & $\begin{array}{c}\text { Sangat } \\
\text { Sering }\end{array}$ & Sering & $\begin{array}{c}\text { Kadang- } \\
\text { Kadang }\end{array}$ & Pernah & $\begin{array}{c}\text { Tidak } \\
\text { Pernah }\end{array}$ \\
\hline 10 & Bingung menentukan metode mengajar yang & $6 \%$ & $23,1 \%$ & $34,9 \%$ & $30,4 \%$ & $8 \%$ \\
& tepat & & & & & \\
11 & Kesulitan membuat perencanaan pembelajaran & $4 \%$ & $20,5 \%$ & $34,1 \%$ & $28,7 \%$ & $13,9 \%$ \\
12 & $\begin{array}{l}\text { Bingung menentukan media pembelajaran yang } \\
\text { relevan }\end{array}$ & $4 \%$ & $23,4 \%$ & $34,4 \%$ & $30,8 \%$ & $8 \%$ \\
\hline
\end{tabular}

Hasil penelitian terkait indikator Kendala Materi Pembelajaran menunjukkan hasil sebagaimana tertuang pada tabel 3 berikut ini.

Tabel 3 Kendala Materi Pembelajaran

\begin{tabular}{llccccc}
\hline No & Kendala Materi Pembelajaran & $\begin{array}{c}\text { Sangat } \\
\text { Sering }\end{array}$ & Sering & $\begin{array}{c}\text { Kadang- } \\
\text { Kadang }\end{array}$ & Pernah & $\begin{array}{c}\text { Tidak } \\
\text { Pernah }\end{array}$ \\
\hline 13 & $\begin{array}{l}\text { Bingung menentukan kegiatan/materi } \\
\text { belajar yang tepat }\end{array}$ & $6 \%$ & $19,3 \%$ & $36,4 \%$ & $29,1 \%$ & $12,8 \%$ \\
14 & $\begin{array}{l}\text { Kesulitan mendeskripsikan penilaian } \\
\text { perkembangan anak }\end{array}$ & $4 \%$ & $24,9 \%$ & $34,6 \%$ & $25,8 \%$ & $11,7 \%$ \\
15 & $\begin{array}{l}\text { Kesulitan memperoleh pedoman } \\
\text { pembelajaran untuk PAUD selama } \\
\text { pandemi Covid 19 }\end{array}$ & $7 \%$ & $31,7 \%$ & $25,7 \%$ & $27,6 \%$ & $9,4 \%$ \\
\hline
\end{tabular}

Hasil penelitian terkait indikator Kendala Biaya dan Penggunaan Teknologi menunjukkan hasil sebagaimana tertuang pada tabel 4 berikut ini.

Tabel 4 Kendala Biaya \& Penggunaan Teknologi

\begin{tabular}{clccccc}
\hline No & \multicolumn{1}{c}{$\begin{array}{c}\text { Kendala Biaya \& Penggunaan } \\
\text { Teknologi }\end{array}$} & $\begin{array}{c}\text { Sangat } \\
\text { Sering }\end{array}$ & Sering & $\begin{array}{c}\text { Kadang- } \\
\text { Kadang }\end{array}$ & Pernah & $\begin{array}{c}\text { Tidak } \\
\text { Pernah }\end{array}$ \\
\hline 17 & $\begin{array}{l}\text { Kesulitan dalam menggunakan media } \\
\text { untuk belajar secara online }\end{array}$ & $7,4 \%$ & $33,7 \%$ & $26 \%$ & $21,4 \%$ & $11.4 \%$ \\
18 & $\begin{array}{l}\text { Keterbatasan biaya untuk membeli } \\
\text { kuota internet }\end{array}$ & $25,9 \%$ & $33 \%$ & $16,5 \%$ & $16,8 \%$ & $7,9 \%$ \\
19 & $\begin{array}{l}\text { Kesulitan untuk memiliki alat mengajar } \\
\text { secara online (HP dan atau Laptop) }\end{array}$ & $14,2 \%$ & $25 \%$ & $18,4 \%$ & $18,9 \%$ & $23,5 \%$ \\
20 & Terkendala jaringan/akses internet & $24,8 \%$ & $33,5 \%$ & $21,7 \%$ & $13,7 \%$ & $7 \%$ \\
\hline
\end{tabular}

Corona melanda dunia, semua sektor terhenti sejenak dan tidak dapat menjalankan aktivitasnya secara normal, begitu pula dengan pembelajaran dan proses mengajar guru anak usia dini, semua guru dituntut mampu melakukan dan menyampaikan pembelajaran jarak jauh padahal hal tersebut merupakan sesuatu yang baru dan bahkan belum pernah dilakukan maka timbullah berbagai permasalahan yang dihadapi guru anak usia dini, hal ini disampaikan (Zaharah \& Kirilova, 2020), Obstacles to implementing this E-Learning certainly exist, for example, internet networks are not met, students are not used to, teachers, and even parents as a companion studying at home to do online learning. This is certainly a normal thing because it has not become a habit for students and teachers to implement KBM in the future, a process that requires better learning outcomes. Maka berikut hasil analisis hasil penelitian kendala guru anak usia dini mengajar saat pandemi corona. 
Berdasarkan hasil penelitian terkait dengan indikator kendala komunikasi tampak bahwa guru-guru PAUD selama pandemi covid 19 mengalami kendala pada kategori sering dan kadang-kadang dengan prosentase yang tinggi hampir pada semua pernyataan yang diajukan yaitu dari mulai sulit untuk menemukan kesamaan pemikiran dengan orang tua tentang tujuan belajar anak (terkait target yang harus dicapai), banyak tuntutan dari orang tua yang sebenarnya tidak menjadi kebutuhan anak, terjadi kesulitan berkoordinasi dengan teman sejawat dalam membuat keputusan (salah satunya karena kendala keterbatasan akses internet) sampai dengan kesulitan membangkitkan semangat belajar anak bahkan pada pernyataan terkait dengan kendala berupa Orang tua tidak memberikan informasi yang sebenarnya terjadi tentang kegiatan anak di rumah, kesulitan berinteraksi secara langsung dengan anak melalui media online dan kesulitan berkomunikasi dengan orang tua dan anak karena tidak memiliki alat komunikasi (HP/Laptop) berada pada prosentase sangat sering.

Fakta ini selaras dengan penelitian yang dilakukan oleh (Duta et al., 2015), (Awang \& Daud, 2015) yang menandaskan bahwa komunikasi merupakan variabel penting dalam interaksi pembelajaran dan berhubungan langsung dengan tujuan pembelajaran supaya tercapai secara efektif. Jika komunikasi terhambat, maka kegiatan pembelajaran juga akan terganggu sebab pembelajaran pada dasarnya merupakan interaksi guru dengan anak didik yang harus bersifat setara. Jika tidak terjadi kesetaraan, maka akan ada satu pihak yang tidak mendapatkan keuntungan. Ketidaksetaraan tersebut diantaranya terkendala karena wabah covid 19 yang menyebabkan kualitas komunikasi dalam pembelajaran antara guru dengan anak di PAUD tidak tercapai secara optimal. Keefektifan komunikasi yaitu dimana seorang guru dapat menyampaiakan pesan atau materinya kepada peserta didik, dan peserta didik dapat memahami materi yang disampikan sebagaimana pemahaman guru tersebut, sehingga pembelajaran bermakna dapat terbangun melalui komunikasi guru dan peserta didik yang baik (Wisman, 2017).

Setidaknya ada tiga unsur yang perlu diperhatikan dalam suatu komunikasi pembelajaran yang efektif. Unsur pertama komunikator, dua isi pernyataan atau pesan dan tiga komunikan atau rekan komunikasi. Dalam kegiatan pembelajaran ketiga unsur ini menjadi sesuatu yang penting apalagi pada kegiatan pembelajaran anak usia dini. Interaksi pembelajaran seyoginya terjadi secara menyenangkan, bermakna, menginspirasi dan membantu anak membangun gagasan sebab anak sedang pada pada masa yang senang mengekplorasi lingkungan dan aktif mencari pengalaman-pengalaman baru (Nurihsan \& Agustin, 2011). Pendek kata, kendala komunikasi dalam kegiatan pembelajaran anak usia dini pada masa pandemi covid 19 turut mengganggu iklim belajar anak usia dini dan itu akan turut berpengaruh pada area-area perkembangan anak usia dini secara keseluruhan. Hal ini dipengaruhi juga oleh pola asuh orang tua, pendidikan orang tua dan lingkungan sekitar (Pramudyani, 2020), (Agustin, Djoehaeni, \& Dwi Puspita, 2020). Orang tua juga membantu guru untuk mengerjakan tugas-tugas kegiatan pengembangan di rumah (Kurniati, Nur Alfaeni, \& Andriani, 2020). Komunikasi tidak terbangun dengan baik antara guru dan anakpun dikarenakan orang tua terutama orang tua yang berada didaerah merasakan keberatan jika harus menambah pengeluaran untuk pembelian kuota internet pembelajaran, berdasarkan penelitian, (Purwanto et al., 2020), kendala yang dihadapi para orang tua adalah adanya penambahan biaya pembelian kuota internet bertambah, teknologi online memerlukan koneksi jaringan ke internetvdan kuota oleh karena itu tingkat penggunaaan kuota internet akan bertambah dan akan menambah beban pengeluaran orang tua.

Terkait dengan kendala metode pembelajaran tampak bahwa guru PAUD mengalami kebingungan menentukan metode mengajar yang tepat pada masa pandemi covid 19, mereka juga terkendala dalam membuat perencanaan pembelajaran dan kebingungan menentukan media pembelajaran yang tepat untuk belajar anak usia dini pada masa pandemi covid 19 ini. Pada ketiga pernyataan tersebut prosentase yang besar berada 
pada kategori sering dan kadang-kadang. Artinya guru-guru PAUD pada masa pandemi covid 19 ini memang mengalami kendala pada pemilihan dan penentuan metode pembelajaran untuk anak. Padahal metode pembelajaran dalam kegiatan belajar anak usia dini memegang peranan yang sangat penting. lebih lanjut, seorang guru di PAUD harus mampu dan paham dalam menerapkan metode pembelajaran yang bervariasi sehingga guru dapat merancang pembelajaran yang menarik, menyenangkan, dan bermakna. Hal tersebut diharapkan agar peserta didik dapat memahami pembelajaran yang dilakukannya lebih baik dan berbekas lama diri anak didik.

Solehuddin, (2018) menegaskan tentang perlunya penerapan metode pembelajaran anak usia dini yang seyogianya dilakukan guru PAUD yaitu mendorong anak supaya aktif dalam melakukan kegiatan terutama bermain dalam situasi yang menyenangkan, terutama melalui projek atau pusat belajar, kegiatan pembelajaran dibangun berdasarkan pengalaman dan minat anak, mendorong terjadinya komunikasi saat belajar baik secara individual atau pun kelompok, guru mendorong anak untuk berani mengambil resiko dan belajar dari kesalahan, memperhatikan variasi dan dinamika perkembangan anak serta metode pembelajaran yang dilakukan bersifat fleksibel. Bermain menjadi metode utama pembelajaran anak usia dini. Pandemi covid 19 salah satunya menyebabkan anak-anak kehilangan kesempatan bermain bersama dengan teman-temannya yang lain juga gurunya di sekolah padahal bermain memegang peranan penting. Bagi anak, bermain adalah suatu kegiatan yang serius, namun mengasyikan. Melalui aktivitas bermain, berbagai pekerjaannya terwujud. Bermain adalah aktivitas yang dipilih sendiri oleh anak, karena menyenangkan, bukan karena akan memperoleh hadiah atau pujian. Hal ini berdasarkan asumsi bahwa anak adalah pembangun teori yang aktif. Bermain adalah salah satu alat utama yang menjadi latihan untuk pertumbuhannya. Bermain adalah medium, di mana anak mencobakan diri, bukan saja dalam fantasinya tetapi juga benar nyata secara aktif. Bila anak bermain secara bebas, sesuai kemauan maupun sesuai kecepatannya sendiri, maka ia melatih kemampuannya. (Solehuddin, 2018). Maka (Armstrong, 2006) menggambarkan tentang pentingnya menerapkan metode pembelajaran yang sesuai dengan perkembangan anak yang ditandai dengan hal-hal sebagai berikut adanya kegiatan bermain tanpa akhir, jam sekolah sangat singkat, ada waktu untuk anak tidur siang, pembelajaran informal sepanjang waktu, adanya keterlibatan orang tua di sekolah, kebanyakan waktu dipakai untuk bergerak dan belajar, pendokumentasian pengalaman anak dan apa yang mereka temukan tentang dunia, jiwa dan alam mereka, program bersifat terpusat pada anak, tidak ada alat berteknologi tinggi bahkan sebaliknya pengalaman multiinderawi ditekankan, banyak waktu bermain tidak terstruktur, ada banyak peluang untuk kegiatan spontan, bermanfaat dan menyenangkan, menghargai integritas, keutuhan, dan kebijakan anak kecil dan memberikan kebebasan kepada anak untuk memilih kegiatannya sendiri.

Hasil penelitian terkait kendala materi pembelajaran menunjukkan bahwa guru PAUD saat pandemi covid 19 sebagian besar mengalami kendala dalam hal menentukan kegiatan/materi belajar yang tepat, mendeskripsikan penilaian perkembangan anak dan juga mengalami kesulitan dalam memperoleh pedoman pembelajaran untuk PAUD selama pandemi Covid 19. Pada pernyataan-pernyataan tersebut prosentasenya berada pada kategori sering dan kadang-kadang. Kegiatan perencanaan pembelajaran tentunya bagian yang sangat penting dalam kegiatan pembelajaran anak usia dini. Apalagi kegiatan pembelajaran di PAUD bersifat tematik dan terintegratif sehingga dituntut kejelian, keseriusan dan juga kreativitas guru dalam melakukannya.

Pembelajaran tematik merupakan adalah pembelajaran yang didasarkan atas ide-ide pokok tentang anak dan lingkungannya berdasarkan kebutuhan mereka, yang mengintegrasikan bidang-bidang pengembangan atau area kurikulum yang mencakup berbagai bidang kajian ilmu. Menurut (Apriyanti, 2017) keutamaan dari pembelajaran tematik adalah pengalaman dan pengajaran sesuai dengan perkembangan anak, menyenngkan, bermakna dan mengasah keterampilan sosial anak. Memadukan ide-ide 
sentral/ ide-ide pokok tentang anak dan lingkungannya melalui proses eksplorasi yang dimulai dari hal-hal yang familier menuju yang lebih jauh, dari hal kongkrit menuju abstrak, dari yang mudah menuju yang sulit. Dalam proses inilah terjadi keaktifan yang bukan hanya melibatkan anak, akan tetapi melibatkan guru dan anak. Dalam konteks pembelajaran terpusat pada anak dan juga terintegrasi anak berkembang secara holistik (menyeluruh) antara aspek perkembangan yang satu dengan aspek perkembangan lainnya. Aspek perkembangan yang satu mempengaruhi dan dipengaruhi oleh aspek perkembangan lainnya.

Implikasinya: Kurikulum PAUD dan SD harus mengintegrasikan seluruh aspek perkembangan anak yaitu kurikulum terpadu. Pada masa pandemi covid 19 tentunya guru PAUD akan mengalami kendala untuk menerapkan prosedur baku pembelajaran terpadu apalagi mereka juga terkendala dalam menerapakan kegiatan penilaian perkembangan anak. Penilaian perkembangan anak usia dini tentunya berbeda dengan penilaian pembelajaran pada jenjang yang berada di atasnya. Penilaian perkembangan anak usia dini lebih menggunakan penilaian yang bersifat alternatif, deskriptif dan menuntut guru untuk lebih banyak melakukan kegiatan observasi dan wawancara untuk melakukannya. Berbeda dengan penilaian mata pelajaran yang bersifat pencil and paper test. Penilaian perkembangan menjadi salah satu kegiatan yang memiliki peranan penting dalam kegiatan pendidikan anak usia dini. Kegiatan penilaian perkembangan anak merupakan usaha mengumpulkan dan menafsirkan berbagai informasi secara sistematis, berkala, berkelanjutan, menyeluruh tentang proses dan hasil dari pertumbuhan serta perkembangan yang telah dicapai oleh anak didik melalui kegiatan pembelajaran. Artinya penilaian perkembangan anak memberikan kontribusi kepada guru dalam mengidentifikasi selain perkembangan juga permasalahan yang dihadapi anak agar dapat dipertimbangkan keputusan yang tepat pada proses selanjutnya.

Pada sisi yang lain, kegiatan penilaian perkembangan anak dapat dijadikan sebagai salah satu cara membantu pendidik dalam memantau proses, kemajuan, dan perbaikan pembelajaran anak secara berkesinambungan sehingga dapat memberikan umpan balik bagi pendidik dalam menyempurnakan proses dan produk pembelajaran. Penilaian perkembangan PAUD mencakup seluruh aspek perkembangan anak. Aspek yang dinilai pendidik mencakup semua program pengembangan yang ada dalam kompetensi dasar yakni kompetensi sikap religius, sikap sosial, pengetahuan dan keterampilan sesuai dengan usia dan tahapan perkembangan anak. Menurut Lina et al., (2019) penilaian pada pembelajaran anak usia dinimelalui pengamatan dan interaksi anak dengan temannya sehingga guru dapat mengenali kemampuan yang dimiliki anak dan guru dapat pula mengetahui cara mengembangkan kemampuan yang dimiliki anak.

Dengan demikian, kegiatan penilaian perkembangan anak usia dini merupakan kegiatan yang sangat penting dalam serangkaian program pembelajaran secara keseluruhan sehingga perlu ada panduan dalam bentuk buku yang komprehensif tapi praktis yang dapat dijadikan salah satu acuan bagi pendidik dalam menyelenggarakan kegiatan penilaian perkembangan anak sehingga dapat tercapai perkembangan anak secara optimal dan dapat membantu pendidik dalam mengatasi berbagai permasalahan anak dengan tepat dan bermakna (Wahyudin \& Agustin, 2011).

Guru PAUD juga terkendala dalam memperoleh pedoman pembelajaran jarak jauh saat pandemi covid 19 yang berakibat kegiatan mengajar dirasakan tidak mencapai tujuan yang diharapkan secara optimal. Padahal pedoman pembelajaran merupakan rambu-rambu yang banyak membantu kegiatan pembelajaran apalagi di PAUD dimana kegiatan pembelajaran dituntut untuk lebih interaktif, kreatif, bermakna dan menyenangkan (Agustin, 2018). Maka dalam pembelajaran di tengah pandemi corona sebaiknya guru banyak melibatkan orang tua dalam menyampaikan materi maupun penggunaan metode pembalajaran yang sesuai dengan perkembangan anak, sesuai dengan reserch Lewis et al., (2011), The five main teaching practices and strategies to engage parents are practicing parent 
outreach, establishing relationships with the parents, creating a positive classroom climate, teaching to involve parents, and making the community school connection, melibatkan orang tua dalam pembelajaran anak sehingga iklim kondusif dan pembelajaran bermakna dapat terwujud.

Hasil penelitian terkait dengan kendala biaya dan penggunaan teknologi pada semua pernyataan menunjukkan prosentase yang tinggi pada kriteria sangat sering dan sering yaitu pada pernyataan kesulitan dalam menggunakan media untuk belajar secara online, keterbatasan biaya untuk membeli kuota internet, kesulitan untuk memiliki alat mengajar secara online (HP dan atau Laptop), dan terkendala jaringan/akses internet. Padahal pembelajaran yang berkualitas tercermin dari kemungkinan anak didik dapat dengan mudah mengaskes bahan, media dan lingkungan belajar secara bebas yang melibatkan berbagai aspek perkembangan mereka, dalam konteks anak usia dini melibatkan perkembangan fisik motorik, kognitif, sosial, emosi, seni dan juga moral/agama. Penggunaan media pembelajaran berbasis teknologi pada beberapa kajian juga turut berkontribusi terhadap hasil belajar anak sehingga dapat disimpulkan bahwa teknologi informasi selain menjadi alat juga menjadi fasilitator efektivitas pembelajaran (Ismaniati, 2013), (Harun, 2015).

Walaupun tidak dapat dipungkiri bahwa salah satu tuntutan pasca pandemi covid 19 kegiatan pembelajaran akan menekankan pada penerapan pembelajaran berbasis teknologi informasi sebagai bagian dari upaya melakukan penyesuaian dengan lingkungan belajar. Itu yang disebut sebagai masa distrupsi yang minimal menutut tigal hal kesiapan untuk melakukan penyesuaian, kesiapan untuk berubah dan kesiapan untuk berkompetisi (Kasali, 2017), (Warsita, 2018). Hasil penelitian menunjukkan realitas bahwa guru-guru PAUD turut terbebani secara finansial dengan kegiatan pembelajaran jarak jauh berbasis internet. Mereka juga tidak semuanya memiliki perangkat yang dapat membantu mempermudah pembelajaran jarak jauh seperti laptop dan HP. Kondisi itupun terjadi pada orang tua anak sehingga pembelajaran secara jarak jauh terkendala secara biaya dan penggunaan teknologi. Padahal seorang guru diharapkan memahami dan menfasilitasi aspek tugas perkembangan peserta didiknya baik secara kognitif, afektif, psikomotor, sosial, emosional, dan spiritualnya sehingga dapat menerapkan pembelajaran yang holistik dan efektif.

Kendala ini perlu solusi yang segera, apalagi jika pemerintah benar-benar akan segera menerapkan kehidupan normal baru yaitu bentuk trasformasi kehidupan baru dengan perilaku baru pada saat pandemi masih mewabah sampai benar-benar ditemukan vaksin yang akurat untuk mengatasi covid 19. implikasinya dalam kegiatan pembelajaran di PAUD akan menuntut perlunya penyesuaian dalam berbagai hal termasuk prosedurprosedur pembelajaran di PAUD perlu edukasi, simulasi dan pelatihan yang memerlukan pemahaman yang utuh, sama dan simultan supaya mendapatkan hasil yang optimal. Strategi pendidik anak usia dini era covid-19 yaitu pelibatan orang tua pada stimulasi perkembangan anak usia dini. Guru PAUD di sekolah melakukan dua tugas pokok sebagai guru yaitu perencana dan penilai hasil perkembangan anak usia dini sementara pendidik PAUD di rumah (orang tua) berfungsi sebagai pelaksana pembelajaran dengan memanfaatkan strategi diskusi (percapakan/tanya jawab) dan keteladanan (Hewi \& Asnawati, 2020).

Pemerintah juga dituntut untuk memperhatikan kecemasan guru dalam melaksanakan proses pembelajaran yang disampaikan dari rumah karena ini merupakan hal yang tidak biasa dan bahkan menjhadi hal yang luar biasa bagi guru di daerah untuk melakukan pengajaran dari urmah terhadap anak didiknya, Further studies should be conducted that focus on the effectiveness of social media for communication purposes amid the health crisis and an in-depth investigation should be made that examines the effects of the pandemic to the emotional and mental well-being of the Filipino teachers including the population of the student community (Talidong \& Toquero, 2020). Karena guru adalah garda terdepan dalam dunia pendidikan. 


\section{SIMPULAN}

Hasil penelitian menunjukkan bahwa kendala mengajar yang dialami guru PAUD pada masa pandemi covid 19 mencakup empat indikator yaitu indikator yaitu (1) indikator Kendala Komunikasi (2) indikator Kendala Metode Pembelajaran (3) indikator Kendala Materi dan (4) indikator Kendala Biaya \& Penggunaan Teknologi. Hasil penelitian menunjukkan bahwa pada semua indikator mengalami kendala mengajar dengan prosentatase yang tinggi pada kriteria sering dan kadang-kadang bahkan pada indikator Kendala Biaya \& Penggunaan Teknologi prosentase yang tinggi berada pada kriteria sering dan sangat sering yaitu meliputi pada pernyataan kesulitan dalam menggunakan media untuk belajar secara online, keterbatasan biaya untuk membeli kuota internet, kesulitan untuk memiliki alat mengajar secara online (HP dan atau Laptop), dan terkendala jaringan/akses internet. Pemerintah perlu menerapkan strategi yang akurat dan matang pada saat penerapan pembelajaran era normal baru dari mulai persiapan, pelaksanaan sampai dengan evaluasi jangan sampai anak-anak didik menjadi korban tahap berikutnya dari keganasan covid 19.

\section{UCAPAN TERIMA KASIH}

Penulis mengucapkan terimakasih kepada dewan editor dan redaksi Jurnal Obsesi yang telah berkenan untuk menerbitkan artikel ini. Penulis juga mengucapkan terimakasih kepada guru-guru PAUD/TK/RA yang telah bersedia menjadi responden dan membantu kelancaran penelitian ini.

\section{DAFTAR PUSTAKA}

Agustin, M. (2011). Permasalahan belajar dan inovasi pembelajaran. Bandung: Refika Aditama. Agustin, M. (2018). Mengajar yang Menyenangkan dan Bermakna Bagi Anak. Bandung: CV Edenia Ciptawira Mandiri.

Agustin, M., Djoehaeni, H., \& Dwi Puspita, R. (2020). Observational Analysis of Violence On Children and the Implications for Parenting Program Development. Pacific Early Childhood Education Research Association, 14(2), 195-214. https:/ / doi.org/10.17206/apjrece.2020.14.2.195

Agustin, M., Setiyadi, R., \& Puspita, R. D. (2020). Burnout Profile of Elementary School Teacher Education Students (Estes): Factors and Implication of Guidance and Counseling Services. PrimaryEdu - Journal of Primary Education, 4(1), 38. https://doi.org/10.22460/pej.v4i1.1640

Apriyanti, H. (2017). Pemahaman Guru Pendidikan Anak Usia Dini Terhadap Perencanaan Pembelajaran Tematik. Jurnal Obsesi : Jurnal Pendidikan Anak Usia Dini, 1(2), 111. https://doi.org/10.31004/obsesi.v1i2.22

Armstrong, M. (2006). A handbook of human resource management practice. Kogan Page Publishers.

Awang, H., \& Daud, Z. (2015). Improving a Communication Skill Through the Learning Approach Towards the Environment of Engineering Classroom. Procedia - Social and Behavioral Sciences, 195, 480-486. https:/ / doi.org/10.1016/j.sbspro.2015.06.241

Creswell, J. W., \& Creswell, J. D. (2017). Research design: Qualitative, quantitative, and mixed methods approaches. Sage publications.

Daulae, T. H. (2014). Menciptakan Pembelajaran yang Efektif. Forum Pedagogik, 06(02), 134.

Duta, N., Panisoara, G., \& Panisoara, I.-O. (2015). The Effective Communication in Teaching. Diagnostic Study Regarding the Academic Learning Motivation to Students. Procedia - Social and Behavioral Sciences, 186, 1007-1012. https://doi.org/10.1016/j.sbspro.2015.04.064

Ernofalina, E. (2017). Culture Shocks Experienced by Indonesian Students Studying Overseas. International Journal of Educational Best Practices, 1(2), 87. 
https:// doi.org/10.31258/ijebp.v1n2.p87-105

Gore, J., Lloyd, A., Smith, M., Bowe, J., Ellis, H., \& Lubans, D. (2017). Effects of professional development on the quality of teaching: Results from a randomised controlled trial of Quality Teaching Rounds. Teaching and Teacher Education, 68, 99-113. https://doi.org/10.1016/j.tate.2017.08.007

Harun, I. (2015). Efektifitas Penggunaan Teknologi Informasi Dan Komunikasi Dalam Pembelajaran Pendidikan Agama Islam. POTENSIA: Jurnal Kependidikan Islam, 1(2), 175-190. https:// doi.org/10.24014/POTENSIA.V1I2.1449

Hewi, L., \& Asnawati, L. (2020). Strategi Pendidik Anak Usia Dini Era Covid-19 dalam Menumbuhkan Kemampuan Berfikir Logis. Jurnal Obsesi : Jurnal Pendidikan Anak Usia Dini, 5(1), 158. https:/ / doi.org/10.31004/obsesi.v5i1.530

Ismaniati, C. (2013). Penggunaan Teknologi Informasi dan Komunikasi dalam Peningkatan Kualitas Pembelajaran. 15.

Kasali, R. (2017). Disruption" Tak ada yang tak bisa diubah sebelum dihadapi motvasi saja tidak cukup".

Kementerian Pendidikan dan Kebudayaan Republik Indonesia. (2020). Surat Edaran Menteri Pendidikan dan Kebudayaan Republik Indonesia Nomor 35952/MPK.A/HK/2020. 1-2.

Khan, A., Khan, S., Zia-Ul-Islam, S., \& Khan, M. (2017). Communication Skills of a Teacher and Its Role in the Development of the Students' Academic Success. Journal of Education and Practice, 8(1), 18-21.

Kurniati, E., Nur Alfaeni, D. K., \& Andriani, F. (2020). Analisis Peran Orang Tua dalam Mendampingi Anak di Masa Pandemi Covid-19. Jurnal Obsesi : Jurnal Pendidikan Anak Usia Dini, 5(1), 241. https:// doi.org/10.31004/obsesi.v5i1.541

Lewis, L. L., Kim, Y. A., \& Ashby Bey, J. (2011). Teaching practices and strategies to involve inner-city parents at home and in the school. Teaching and Teacher Education, 27(1), 221-234. https://doi.org/10.1016/j.tate.2010.08.005

Lina, L., Suryana, D., \& Nurhafizah, N. (2019). Penerapan Model Evaluasi CIPP dalam Mengevaluasi Program Layanan PAUD Holistik Integratif. Jurnal Obsesi : Jurnal Pendidikan Anak Usia Dini, 3(2), 346. https:/ / doi.org/10.31004/obsesi.v3i2.200

Maiza, Z., \& Nurhafizah, N. (2019). Pengembangan Keprofesian Berkelanjutan dalam Meningkatkan Profesionalisme Guru Pendidikan Anak Usia Dini. Jurnal Obsesi : Jurnal Pendidikan Anak Usia Dini, 3(2), 356. https:// doi.org/10.31004/obsesi.v3i2.196

Nurihsan, A. J., \& Agustin, M. (2011). Dinamika perkembangan anak dan remaja: Tinjauan psikologi, pendidikan, dan bimbingan. Bandung: Refika Aditama.

Panjaitan, N. Q., Yetti, E., \& Nurani, Y. (2020). Pengaruh Media Pembelajaran Digital Animasi dan Kepercayaan Diri terhadap Hasil Belajar Pendidikan Agama Islam Anak. Jurnal Obsesi : Jurnal Pendidikan Anak Usia Dini, 4(2), 588. https:// doi.org/10.31004/obsesi.v4i2.404

Pramudiana, I. D., \& Setyorini, T. D. (2019). Hubungan Antara Gegar Budaya Dengan Penyesuaian Sosial Siswa Papua di Magelang. PRAXIS, 1(2), 125. https:// doi.org/10.24167/ praxis.v1i2.1631

Pramudyani, A. V. R. (2020). The Effect of Parenting Styles for Children's Behaviour on Using Gadget at Revolution Industry. Jurnal Obsesi : Jurnal Pendidikan Anak Usia Dini, 5(1), 51. https://doi.org/10.31004/obsesi.v5i1.520

Purwanto, A., Pramono, R., Asbari, M., Hyun, C. C., Wijayanti, L. M., Putri, R. S., \& others. (2020). Studi Eksploratif Dampak Pandemi COVID-19 Terhadap Proses Pembelajaran Online di Sekolah Dasar. EduPsyCouns: Journal of Education, Psychology and Counseling, 2(1), 1-12.

Rohita, R. (2020). The Ability of Ece Teachers to Use ICT in The Industrial Revolution 4.0. Jurnal Obsesi : Jurnal Pendidikan Anak Usia Dini, 4(2), 502. https:// doi.org/10.31004/obsesi.v4i2.339

Ronkainen, R., Kuusisto, E., \& Tirri, K. (2019). Growth mindset in teaching: A case study of a 
DOI: 10.31004 /obsesi.v5i1.598

Finnish elementary school teacher. International Journal of Learning, Teaching and Educational Research, 18(8), 141-154. https://doi.org/10.26803/ijlter.18.8.9

Setyosari, P. (2017). Menciptakan Pembelajaran yang Efektif dan Berkualitas. JINOTEP (Jurnal Inovasi Dan Teknologi Pembelajaran) Kajian Dan Riset Dalam Teknologi Pembelajaran, 1(5), 20-30. https://doi.org/10.17977/um031v1i12014p020

Solehuddin, M. (n.d.). dkk. 2008. PembaharuanPendidikan TK. Cetakan Ke-5. Jakarta: Universitas Terbuka.

Talidong, K. J. B., \& Toquero, C. M. D. (2020). Philippine Teachers' Practices to Deal with Anxiety amid COVID-19. Journal of Loss and Trauma, 1-7. https:// doi.org/10.1080/15325024.2020.1759225

Wahyudin, U., \& Agustin, M. (2011). Penilaian perkembangan anak usia dini. Bandung: Refika Aditama.

Warsita, B. (2018). Kecenderungan global dan regional dalam pemanfaatan teknologi informasi dan komunikasi untuk pendidikan. Jurnal Teknodik, 10(19), 069. https://doi.org/10.32550/teknodik.v10i19.394

Wisman, Y. (2017). Komunikasi Efektif Dalam Dunia Pendidikan. Jurnal Nomosleca, 3(2), 646654. https:// doi.org/10.26905/nomosleca.v3i2.2039

Yusuf, B. B. (2017). Konsep Dan Indikator Pembelajaran Efektif. Jurnal Kajian Pembelajaran Dan Keilmuan, Vol. 1, pp. 13-20. Retrieved from http://jurnal.untan.ac.id/index.php/jurnalkpk/article/view/25082/75676576424

Zaharah, Z., \& Kirilova, G. I. (2020). Impact of Corona Virus Outbreak Towards Teaching and Learning Activities in Indonesia. SALAM: Jurnal Sosial Dan Budaya Syar-I, 7(3). https://doi.org/10.15408/sjsbs.v7i3.15104 